\title{
META-ANALYSIS THE EFFECT OF SEXUAL EDUCATION USING SCHOOL BASED INTERVENTION ON THE RISK OF PREGNANCY IN ADOLESCENTS
}

\author{
Jatu Kartika Akmalai), Eti Poncorini Pamungkasari²), \\ Hanung Prasetya3)
}

\author{
${ }^{1)}$ Masters Program in Public Health, Universitas Sebelas Maret \\ 2)Department of Public Health, Faculty of Medicine, Universitas Sebelas Maret
}

\begin{abstract}
Background: Sexually active young people are at high risk of HIV infection. Schoolbased sexual and reproductive health programmes are widely accepted as an approach to reducing high-risk sexual behavior in adolescents. This study was conducted to evaluate the effects of school-based intervention on the risk of pregnancy in adolescents. Subjects and Method: A systematic review and meta analysis was conducted by collecting articles from PubMed, Science Direct, BMJ, and Google Scholar databases. The determination of selected articles based on eligible criteria using PICO: (1) Population= adolescents, (2) Intervention= school based sexual education, (3) Comparison= non school based sexual education, and (4) Outcome= unintended pregnancy. Keywords used "school-based sexual education" OR "school-based sex education" AND "unwanted pregnancy" OR "unintended pregnancy" AND adolescent AND "randomized controlled trial". The inclusion criteria were full text and randomized controlled trial study. The articles were collected by PRISMA flow diagram. The selected articles were quantitatively examined by Review Manager 5.3
\end{abstract}

Results: 9 studies involving from Malawi, Zimbabwe, South Africa, United States, United Kingdom, Scotland, and Ghana showed that school-based sexual education improved unintended pregnancy in adolescents $(\mathrm{OR}=1.04 ; 95 \% \mathrm{CI}=0.95$ to $1.13 ; \mathrm{p}=$ $0.42)$.

Conclusion: School-based sexual education improves unintended pregnancy in adolescents.

Keywords: school-based sexual education, unintended pregnancy, adolescents

\section{Correspondence:}

Jatu Kartika Akmala. Masters Program in Public Health, Universitas Sebelas Maret. Jl. Ir. Sutami 36A, Surakarta 57126, Central Java. Email: jatu.kartika@student.uns.ac.id.

The $8^{\text {th }}$ International Conference on Public Health Solo, Indonesia, November 17-18, $2021 \mid 78$ https://doi.org/10.26911/AB.Promotion.ICPH.08.2021.10 